\title{
STRATEGI CITY BRANDING MELALUI GELARAN BUDAYA TARI SPARKLING SEBAGAI KOMUNIKASI PARIWISATA KOTA SURABAYA
}

\author{
Seyla Pratiwi Lestari \\ Glorya Agustiningsih ${ }^{1}$
}

\begin{abstract}
City branding is a strategy used by a city to build and communicate city's strong positioning regionally and globally through tourism promotion. City branding of Surabaya is a form of Surabaya marketing communication tool in tourism, following the era where cities today rely on branding for packaging and promoting tourism in the city. Sparkling Surabaya promotional activities are carried out in various forms summarized in promotion and cooperation. Promotional material in the form of brochures, books, calendars, posters, pamphlets, stickers, photos, videos, maps, souvenirs, and free magazines can be found at the Tourist Information Center (TIC), hotels, and various other places that are easily accessible to the tourists. One of marketing communications tools of city branding arised nowadays is a cultural event, such as Sparkling Surabaya dance that expresses the city of Surabaya through motion as language of symbols. This study aims to determine the city branding strategy in an effort to promote tourism through the Sparkling dance culture event in Surabaya. The research method uses a qualitative approach with interviews and documentation as data collection techniques. The results of the research are useful for scientific development in the field of communication, especially for city government and the tourism industry in practical terms.
\end{abstract}

Keywords: City Branding, Sparkling Surabaya Dance, Tourism Communication.

\begin{abstract}
Abstrak
City branding adalah strategi dari suatu kota untuk membangun dan mengomunikasikan pemosisian kota yang kuat secara regional maupun global. Melalui city branding dapat dibentuk identitas kota yang berguna untuk kebutuhan pemasaran kota tersebut. City branding yang dilakukan di Surabaya merupakan sebuah bentuk pemasaran Surabaya dari segi pariwisata, di mana kota-kota masa kini mengandalkan branding untuk mengemas dan mempromosikan pariwisata di kotanya. Kegiatan komunikasi "Sparkling Surabaya" dilakukan dalam berbagai bentuk yang terangkum dalam bentuk promosi dan kerjasama. Materi promosi berupa brosur, poster, calendar, pamflet, stiker, foto, video, peta, souvenir, dan majalah gratis yang bisa didapatkan di Tourist Information Center (TIC), hotelhotel, dan berbagai tempat lain yang mudah dijangkau wisatawan. Produk komunikasi pemasaran baru muncul untuk menambah kekayaan seni budaya khas Surabaya, yaitu tarian Sparkling Surabaya. Tari Sparkling Surabaya merupakan tarian yang mengekspresikan tentang kota Surabaya. Melalui gerak sebagai bahasa simbol menyimpan makna yang tersimpan. Ada sebuah pemahaman yang dibangun melalui makna tersebut yang berisi tentang kota Surabaya. Penelitian ini bertujuan untuk menganalis strategi city branding dalam upaya untuk mengomunikasikan wisata melalui gelaran budaya tari Sparkling Surabaya. Metode penelitian menggunakan pendekatan kualitatif dengan wawancara dan dokumentasi sebagai teknik pengumpulan data. Hasil dari penelitian bermanfaat bagi pengembangan keilmuan di bidang komunikasi, khususnya bagi pemerintah kota dan industri pariwisata secara praktis.
\end{abstract}

Kata Kunci: City Branding, Tari Sparkling Surabaya, Komunikasi Pariwisata.

\footnotetext{
*Alamat kini: Institut Bisnis dan Informatika Kwik Kian Gie, Jl. Yos Sudarso Kav. 87, Jakarta 14350

Penulis untuk Korespondensi: Telp. (021) 65307062 Ext. 705, Email: glorya.agustiningsih@kwikkiangie.ac.id
} 


\section{Pendahuluan}

Era modern seperti saat ini menuntut manusia untuk selalu berkembang demi menyesuaikan perubahan zaman. sama halnya dengan manusia, sebuah kota pun perlu melakukan perubahan demi mempertahankan eksistensinya. Perubahan dan perkembangan kota ini menimbulkan fenomena baru pada masyarakat modern, yaitu menginginkan adanya pengakuan atas kotanya yang menimbulkan kebanggaan tersendiri jika tinggal atau berasal dari kota yang memiliki citra positif. Oleh karena itu, pemerintah kota berupaya untuk meningkatkan citra dari kotanya

Fenomena city branding sekarang ini menjadi tren di berbagai negara yang bertujuan untuk meningkatkan perekonomian negara atau kota tersebut, terutama melalui sektor pariwisata. Sektor pariwisata merupakan sektor yang strategis karena dapat berkontribusi terhadap pertumbuhan perekonomian, menciptakan lapangan kerja, perkembangan investasi, peningkatan pendapatan masyarakat, serta penerimaan keuangan negara.

Dalam rangka membentuk citra tertentu, pemerintah kota menerapkan strategi khusus yang biasanya disebut dengan city branding. City branding adalah konsep yang membuat suatu tempat seolah-olah 'berbicara' kepada (Yananda \& Salamah, 2014) Dalam strategi city branding sebuah kota tampak seperti berkomunikasi dengan masyarakat mengenai dirinya, seperti halnya city branding Surabaya yang berkomunikasi melalui identitas untuk menanamkan citra dibenak khalayak. Citra inilah yang akan membangun imajinasi dipikiran khalayak mengenai Surabaya.

Sebagai kota wisata, sejak akhir tahun 2005, Surabaya telah berkembang menjadi kota wisata yang berbasis pada wisatawan bisnis. Dengan keberadaan Surabaya Tourism Promotion Board yang bersinergi dengan Dinas Budaya dan Pariwisata kota Surabaya, maka pembenahan pariwisata kota Surabaya mulai dilakukan secara aktif dan membuahkan hasil yang sangat positif. Sejak akhir tahun 2005, dimulai dari rapat perdana di Surabaya Tourism Promotion Board, slogan "Sparkling Surabaya“, mulai diperkenalkan di publik
Surabaya. Pariwisata Indonesia semakin mengalami perkembangan. Tidak hanya Bali, Jakarta, maupun Yogyakarta, Surabaya juga menjadi salah satu kota destinasi wisata di Indonesia.

Pariwisata Surabaya semakin menunjukkan eksistensinya setelah dikeluarkannya surat keputusan Walikota Surabaya No. 188.45/30/436.1.2/2006 tentang pembentukan Surabaya Tourism Promotion Board (STPB), yaitu organisasi non-profit yang memiliki legalitas dalam mempromosikan wisata Surabaya. Secara bersamaan, melengkapi STPB, diluncurkan city branding Sparkling Surabaya. Berbagai upaya dilakukan untuk membangkitkan Pariwisata dan Kesenian di kota Surabaya, Surabaya Tourism Promotion Board dan Dinas Budaya dan Pariwisata kota Surabaya, sedang gencar mempromosikan wisata kota Surabaya dengan brand "Sparkling Surabaya" dengan cara melakukan berbagai macam promosi salah satunya adalah melalui event budaya seperti event tari Sparkling Surabaya. Event tari Sparkling Surabaya sendiri di gunakan sebagai sarana untuk mencari potensi yang ada dari masyarakat Surabaya sendiri.

\section{Tinjauan Pustaka}

\section{City Branding}

City branding merupakan bagian dari perencanaan kota/perkotaan melalui berbagai upaya untuk membangun diferensiasi dan memperkuat identitas kota agar mampu bersaing dengan kota lainnya demi menarik turis, penanaman modal, SDM yang andal, industry, serta meningkatkan kualitas hubungan antara warga dengan kota. Pada awalnya praktik city branding digunakan untuk tujuan ekonomi, namun seiring berjalannya waktu, city branding menjadi perhatian karena globalisasi ekonomi menjadikan kota sebagai modal strategis.

Kegiatan city branding bukan hanya sebatas membuat slogan atau logo. Lebih dari itu, identitas dan apa yang ditampilkan haruslah bersumber dari jiwa kota tersebut. layaknya sebuah produk, pelabelan pada suatu kota harus mempresentasikan segala kepribadian dan 
serba serbi kota yang ditempeli brand tersebut. City branding memiliki tugas yang tidak jauh berbeda dengan branding pada umumnya yaitu upaya untuk mempromosikan image kota yang khas melalui bentuk fisik kota, kebijakan pemerintah kota, promosi periklanan, dan tingkah laku penduduk.

Proses city branding terkait dengan pembentukan identitas kota yang bersifat berbeda dan mengarahkan bagaimana sebuah kota dipasarkan. Branding dilakukan untuk mengamankan kelebihan ekonomi dan kompetitif, pembangunan komunitas dan kohesi, serta meningkatkan ket- erlibatan sipil dan identitas dengan sebuah tempat (Kavaratzis, 2004). Saat sebuah tempat telah bergeser dari produk menjadi brand, maka kota menjadi obyek yang dapat memberikan konfirmasi terhadap identitas.

City branding merupakan bagian dari perencanaan kota/perkotaan melalui berbagai upaya untuk membangun diferensiasi dan memperkuat identitas kota agar mampu bersaing dengan kota lainnya demi menarik turis, penanaman modal, SDM yang andal, industri, serta meningkatkan kualitas hubungan antara warga dengan kota.

\section{Komunikasi Pariwisata}

Komunikasi membantu pemasaran pariwisata di berbagai elemen pemasaran, komunikasi berperan baik di media komunikasi maupun konten komunikasi. Di media komunikasi, tersedia berbagai macam media komunikasi sebagai saluran pemasaran, destinasi, aksesibilitas maupun saluran media SDM dan kelembagaan pariwisata. Komunikasi juga berperan menyiapkan konten pesan yang harus disampaikan kepada masyarakat atau wisatawan, tentang apa yang seharusnya mereka tahu tentang media-media pemasaran, tentang destinasi, aksesibilitas dan SDM serta kelembagaan pariwisata.

Dalam perspektif modern, komponen pemasaran, destinasi, aksesibilitas, SDM, dan kelembagaan pariwisata, serta elemen-elemen yang ada menjadi kesatuan produk pariwisata di sebuah destinasi yang dikemas di dalam suatu brand destinasi, sehingga destinasi, aksesibilitas, pemasaran, SDM dan kelembagaan pariwisata menjadi kesatuan produk pariwisata. Komunikasi pariwisata merupakan suatu aktivitas manusia dalam menyampaikan informasi tentang perjalanan ke suatu daerah atau objek wisata yang akan dikunjungi wisatawan dengan menikmati perjalanan dari suatu objek ke objek wisata lain sehingga wisatawan tertarik dan sampai pada suatu tindakan untuk mengunjungi.

Komponen-komponen itulah yang masih harus diramu kembali sehingga menjadi suatu produk paket wisata yang lengkap. Produk itu dapat disusun sendiri oleh wisatawan yang melakukan perjalanan. Sehingga promosi pun juga harus ditujukan kepada mereka. Ini disebut promosi konsumen atau biasa disebut promosi langsung. Promosi langsung dilakukan oleh semua lembaga yang bersangkutan dengan pemasaran, seperti: produsen paket wisata, biro perjalanan umum dan agen perjalanan (Bungin, 2015)

Banyak wisatawan membayar untuk produk yang sudah jadi yang telah disusun oleh biro perjalanan umum dan ditawarkan kepada wisatawan melalui agen perjalanan. Maka jelaslah bahwa agen perjalanan juga harus dijadikan sasaran promosi. Cara seperti ini adalah promosi tidak langsung. Promosi tidak langsung dapat ditujukan kepada agen perjalanan atau biro perjalanan umum yang mempunyai koneksi dan konsumen yang lumayan banyak (Bagus, 2017)

Tujuan diadakannya kegiatan ini adalah menarik perhatian para agen perjalanan dengan komponen-komponen produk pariwisata yang ditawarkan dan membuat mereka bersedia untuk menjualkannya dan menciptakan kondisi dan menyediakan sarana bagi travel agent untuk menyusun produk wisata yang tepat untuk dijual kepada wisatawan. Dari cara-cara promosi yang dilakukan tersebut, jelaslah bahwa ada promosi yang dilakukan di daerah calon wisatawan tinggal atau di daerah tujuan wisata. Berhasil tidaknya suatu promosi dapat diukur dari banyaknya informasi yang diminta, lalu besarnya volume kedatangan wisatawan.

\section{Gelaran Budaya (Cultural Event)}

Gelaran (event) adalah suatu kegiatan yang diselenggarakan untuk memperingati halhal penting sepanjang hidup manusia baik 
secara individu atau kelompok yang terikat adat, budaya, tradisi, dan agama yang diselenggarakan untuk tujuan tertentu serta melibatkan lingkungan masyarakat yang diselenggarakan pada waktu tertentu (Noor, 2017). Definisi event menurut ahli, diantaranya Shone dan Parry (2002) yang meyatakan bahwa:

"Event adalah fenomena yang muncul dari mereka yang tidak memiliki acara rutin yang memiliki tujuan rekreasi, budaya, pribadi atau organisasi yang terpisah dari kegiatan normal kehidupan sehari-hari, yang tujuannya adalah untuk mencerahkan, merayakan, menghibur atau menantang pengalaman sekelompok orang."

Festival budaya memiliki karakteristik tersendiri. Berdasarkan tujuan dan waktu penyelenggaraan, serta ukuran gelaran. Rofle dan South East Art dalam Bowdin (2003) membagi event budaya menjadi tujuh karakteristik, yaitu :

1. High profile general celebration of the arts Merupakan gelaran yang telah tersusun dalam agenda yang jelas. Memiliki tujuan dengan pencapaian standar yang tinggi, menarik minat media untuk meliput dan menyangkannya secara luas, serta mampu menghasilkan pendapatan yang tinggi.

2. Festival untuk memperingati tempattempat tertentu

Mulai dari daerah kecil sampai kota besar. Festival diselenggarakan dengan tujuan mengumpulkan orang dari daerah yang bersangkutan untuk turut serta mengambil bagian dalam festival tersebut.

3. Art form festival

Fokus pada bentuk seni tertentu. Festival ini menampilkan hasil seni kepada pengunjung dan pada saar yang sama dapat dilakukan diskusi, atau latihan singkat tentang seni tersebut.

4. Celebration of work by a community of interest

Festival yang diselenggarakan oleh orangorang dengan ketertarikan khusus.

5. Calendar
Perayaan yang bersifat religi dan kebudayaan biasanya diselenggarakan berdasarkan tanggal atau waktu tertentu dari suatu kepercayaan tertentu

6. Festival seni amatir

Banyak festival yang diselenggarakan oleh organizer yang masih relatif kecil, tetapi mampu menarik pengunjung dalam jumlah yang besar.

7. Commercial music festival

Merupakan jenis event yang sering diselenggarakan karena sangat popular dan mampu menarik minat pengunjung.

\section{Tari Sparkling Surabaya}

Tari Sparkling Surabaya adalah tarian kreasi baru yang menggambarkan jati diri masyarakat dan kota Surabaya, Jawa Timur. Tarian ini merupakan perpaduan tarian modern dan tradisional yang digarap dengan baik tanpa meninggalkan nilai seni dan budaya yang ada pada kota Surabaya. Walaupun tarian kreasi baru, namun Tari Sparkling Surabaya ini sangat dikenal oleh masyarakat Surabaya dan menjadi salah satu tarian selamat datang bagi para wisatawan atau tamu besar yang datang kesana.

Tari Sparkling Surabaya ini merupakan hasil perpaduan unsur tradisional seperti busana, gerak tari, dan musik tradisional Jawa Timur yang dikemas dengan gaya modern sehingga menampilkan sesuatu yang bebeda dan kaya akan nilai seni dan budaya. Dalam pertunjukannya, Tari Sparkling Surabaya ini ditampilkan oleh $5-10$ orang penari wanita. Gerakan dalam tarian ini cenderung cepat dan lincah dengan gerakan yang selaras dengan musik tradisional yang mengiringinya.

Gerakan ini menggambarkan sifat masyarakat modern Surabaya yang egaliter dan tidak lamban. Selain itu ragam gerakan Tari Sparkling Surabaya ini mengacu pada motif gerak tari tradisional Jawa Timuran yang berkembang di Surabaya. Sehingga walaupun merupakan tarian bernuansa modern namun tidak meninggalkan nilai seni dan budaya yang ada. Music pengiring dalam pertunjukan Tari Sparkling Surabaya ini merupakan perpaduan dari musik tradisional Jawa Timuran yang dikemas dengan nuansa modern.

Dalam musik pengiring ini terdapat berbagai alat musik gamelan dengan laras khas 
Jawa Timuran, yang dipadukan dengan berbagai alat musik perkusi dan lain - lain. Selain itu music tradisional tersebut juga dikolaborasikan dengan alunan lagu daerah, sehingga menampilkan iringan music yang khas namun tetep seirama dengan gerakan dalam tarian ini.

Kostum dalam tarian ini juga merupakan perpaduan busana dan tata rias tari tradisional yang dikemas secara modern. Pada tubuh bagian atas, penari menggunakan kemben dan kebaya pada bagian luarnya. Lalu pada bagian bawah menggunakan kain panjang sepanjang mata kaki. Dan berbagai aksesori pemanis yang membuat penari terlihat sangat cantik. Untuk warna biasanya bisa bermacam macam seperti warna hijau, biru, merah, kuning dan emas. Selain itu yang menjadi ciri khas adalah sayap kain berwarna emas yang digunakan sebagai attribute menari.

Dalam perkembangannya, Tari Sparkling Surabaya mulai diperkenalkan ke masyarakat luas dengan sering ditampilkan di berbagai perayaan atau acara budaya baik dalam negeri maupun manca negara. Selain itu tarian ini juga diangkat sebagai salah satu icon kota Surabaya karena nilai - nilai di dalamnya yang menggambarkan kota Surabaya.

\section{Metode Penelitian}

Dalam penelitian ini, peneliti akan meneliti strategi city branding dalam upaya mempromosikan wisata melalui event budaya tari Sparkling Surabaya yang dilakukan oleh Dinas pariwisata kota Surabaya. Dinas pariwisata kota Surabaya ini terletak di Gedung Siola, Tunjungan St No.1-3, Genteng, Kota Surabaya, Jawa Timur 60275. Menurut Sugiyono (2012:38), objek penelitian adalah suatu atribut atau sifat atau nilai dari orang, objek atau kegiatan yang mempunyai variansi tertentu yang ditetapkan oleh penelitian untuk di pelajari dan kemudian ditarik kesimpulannya.

Pada penelitian ini, yang menjadi subyek penelitian adalah gelaran budaya Tari Sparkling Surabaya. Informan dalam penelitian ini adalah individu yang dianggap peneliti mampu dalam memberikan informasi yang berkaitan dengan gelaran budaya tersebut.
Informan diharuskan mempunyai kapabilitas dan kompetensi untuk memberikan informasi yang terkait, yaitu perwakilan dari Dinas pariwisata kota Surabaya.

Data yang akurat di perlukan data sesuai kondisi di lapangan, sehingga dibutuhkan teknik yang tepat dalam pengumpulan data. Teknik pengumpulan data dalam penelitian ini adalah wawancara dan dokumen, berupa gambar, foto, artikel terkait tentang city branding dalam upaya mempromosikan wisata melalui gelaran budaya yaitu Tari Sparkling Surabaya yang dilakukan oleh Dinas Kebudayaan dan Pariwisata Kota Surabaya yang sangat membantu dalam melengkapi data primer dari sebuah wawanacara.

Teknik analisis data yang digunakan dalam penelitian ini adalah deskriptif kualitatif yaitu teknik analisis data yang digunakan untuk mendeskripsikan strategi city branding dalam upaya mempromosikan wisata melalui event budaya tari Sparkling Surabaya yg di lakukan oleh Dinas Kebudayaan dan Pariwisata Kota Surabaya data yang diperoleh diinterpretasikan, di analisis kemudian dideskripsikan berdasarkan teknik analisis data yang digunakan untuk memperoleh jawaban yang telah dirumuskan. Penelitian kualitatif ini dilakukan pada saat pengumpulan data berlangsung dan setelah selesai pengumpulan data. Dalam penelitian ini menggunakan analisis data dari Miles dan Huberman yaitu model interaktif (Sugiyono, 2017).

\section{Hasil Dan Pembahasan}

City branding Surabaya merupakan sebuah bentuk pemasaran Surabaya dari segi pariwisata, mengikuti zaman di mana kota-kota masa kini mengandalkan branding untuk mengemas dan mempromosikan pariwisata kotanya. 'City' yang berarti kota, mengacu pada sebuah teritorial, yaitu Surabaya. City branding tidak harus bersifat terbatas pada sebuah kota dengan batasan-batasan yurisdiksinya. City branding dapat digunakan sebagai cara menarik wisatawan dengan 'meminjam' pariwisata kota-kota di sekitarnya untuk dijual melalui city branding Surabaya. 
Konsep dan arti dari logo Sparkling Surabaya diambil dari berbagai potensi wisata kota Surabaya yang dilihat dari segi geografis dan karakter destinasi wisata masing-masing. Tulisan Sparkling Surabaya yang menggunakan warna biru menunjukkan bahwa Surabaya merupakan kota pesisir, sedangkan warna hijau menunjukkan bahwa Surabaya adalah kota yang mengedepankan green and clean. Warna hijau juga mewakili kondisi
Surabaya yang punya banyak lapangan golf bertaraf internasional.

Sparkling Surabaya memiliki slogan "You will be love every corner of it". Melalui slogan ini, tersirat keinginan untuk mewujudkan seluruh pojok kota menjadi primadona dengan keunikan tersendiri. Konsep ini tampil dalam visual lima bintang yang mewakili lima sub wilayah Surabaya (Surabaya utara, timur, barat, selatan, dan pusat) pada logo Sparkling Surabaya.

\section{Gambar 4.1}

\section{Logo Sparkling Surabaya}

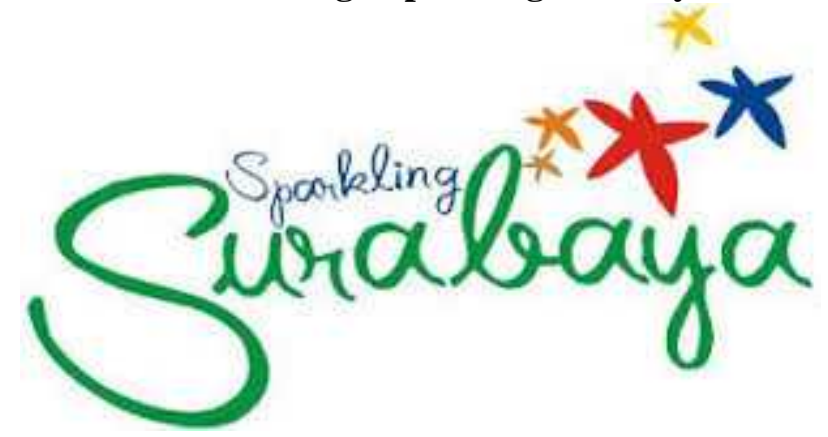

Sumber: Google Logo Sparkling Surabaya

Sparkling Surabaya memposisikan Surabaya sebagai pusat kegiatan dari Indonesia Timur. Perlu diperhatikan bahwa city branding Surabaya merupakan strategi memasarkan Jawa Timur dengan memakai Surabaya sebagai 'etalase'. Strategi yang disebut dengan heartland strategy ini merupakan sebuah strategi pengembangan wisata yang dimulai dari pusat provinsi untuk dikembangkan secara bertahap hingga mencakup seluruh Jawa Timur. Terbukti bahwa pemasaran city branding Surabaya disertai dengan pemasaran atraksi wisata lain di Jawa Timur. Basis pariwisata Surabaya sendiri mengarah pada bisnis, yaitu MICE (Meeting, Incentives, Convention, Exhibition).
Kegiatan promosi Sparkling Surabaya dilakukan dalam berbagai bentuk yang terangkum dalam promosi dan kerjasama. Materi promosi berupa brosur, pamflet, stiker, foto, video, peta, souvenir, dan majalah gratis yang bisa didapatkan di Tourist Information Center (TIC), hotel-hotel, dan berbagai tempat lain yang mudah dijangkau wisatawan. Materi cetak lain adalah calendar of events dalam bentuk buku dan poster, yaitu kalender agenda berisi event-event yang akan diadakan di Surabaya. Selain itu, juga terdapat materi promosional berupa website yang berisi informasi pariwisata Surabaya, serta informasi tentang event-event dan tentang Surabaya sendiri (sejarah, bahasa, dan sebagainya). 


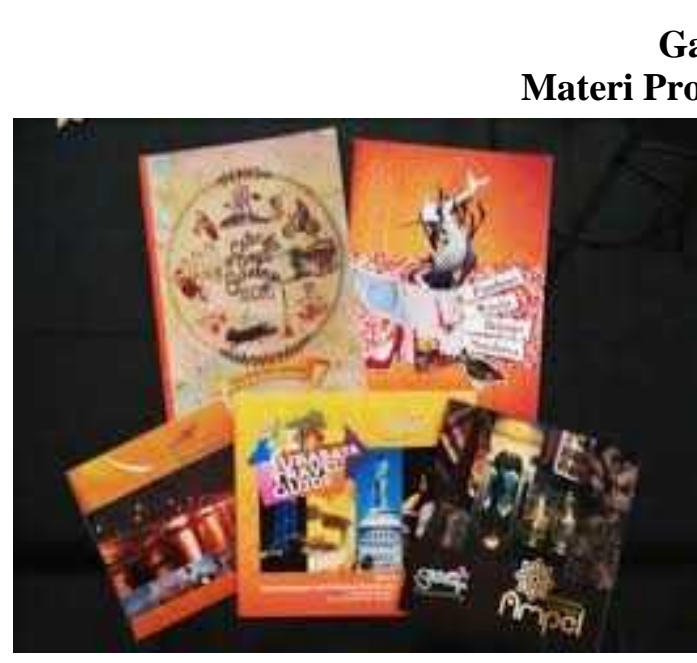

Sumber : Dokumen Dinas Pariwisata Surabaya
Gambar 4.2

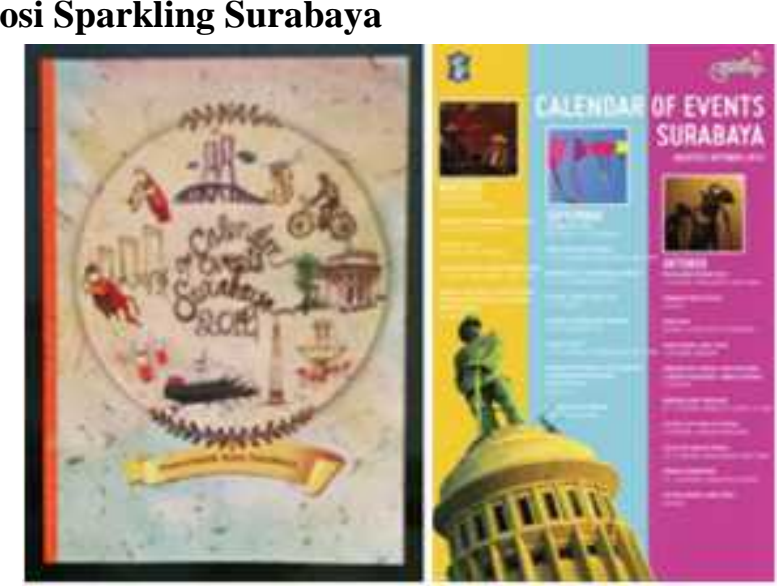

Sumber : Dokumen Dinas Pariwisata Surabaya

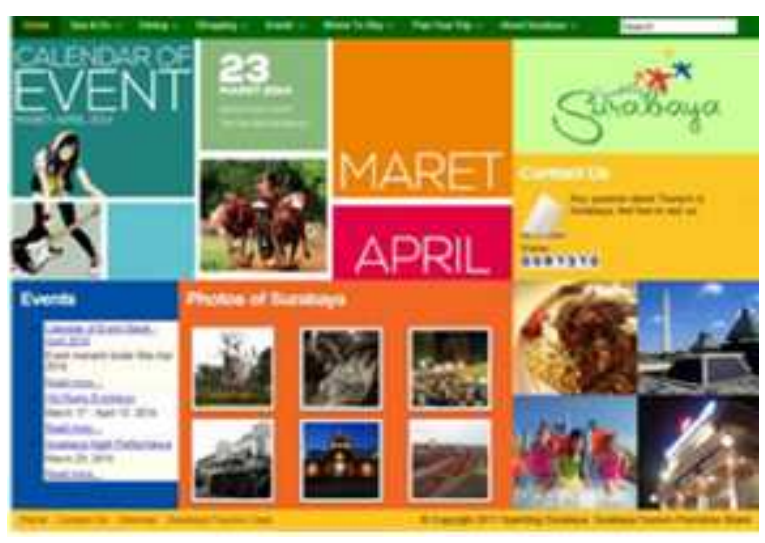

Sumber : Website Resmi Sparkling Surabaya (Sparkling Surabaya, 2015)

Produk promosional baru muncul untuk menambah kekayaan seni budaya khas Surabaya, yaitu tarian Sparkling Surabaya. Tarian yang menjadi persembahan welcoming ke Surabaya ini merupakan modifikasi dari tarian tradisional Jawa Timur. Tarian ini pernah ditampilkan dalam Festival Seni Lintas Budaya 2007 di Balai Kota Surabaya, di luar negeri, dan di Bandara Juanda untuk menyambut penumpang Singapore Airlines yang baru saja tiba. Hal ini sebagaimana di jelaskan oleh Dra. Susarinigsih, M.M, sebagai Kepala Bidang Pemasaran Pariwisata yang menjelaskan bahwa:

"Dalam upaya membangkitkan wisata kota Surabaya, STPB banyak mendapat dukungan tidak hanya dari pelaku wisata, tetapi juga dari pelaku kesenian. Ini terbukti dari terciptanya tarian Surabaya yang diberi nama 'Sparkling Suroboyo'. Sesuai namanya tarian ini memang dipersembahkan untuk melengkapi sarana promosi yang selama ini telah dimiliki dan digunakan oleh STPB. Sparkling Suroboyo sendiri telah diperkenalkan di Yogyakarta dan banyak mendapat dukungan. Rencananya tarian ini juga akan diperkenalkan di Bali, yang terkenal sebagai tempat tujuan wisata. Sparkling Suroboyo telah memiliki perwakilannya, yang tersebar di Swedia, Brunai, Manila, Bali, Balikpapan dan Makasar. Oleh karena itu selain gencar melakukan promosi wisata dan kesenian, STPB juga 
meningkatkan pendekatan pada air line, karena ini merupakan sarana wisatawan mengunjungi Surabaya."

Tari Sparkling Surabaya ini merupakan tarian kreasi yang diciptakan oleh Diaztiarni pada tahun 2007. Tarian ini diciptakan dalam rangka untuk menyambut ulang tahun kota Surabaya ke -714 yang mengambil tema "Surabaya Sparkling". Hal ini sebagaimana telah dinyatakan oleh Diaztiarni Azhar, seorang pimpinan Studio Tydif sekaligus sebagai seniman tari dari Surabaya yang menyatakan bahwa:

"Tarian ini muncul sebagai karya seni di tengah masyarakat Surabaya yang heterogen dan beraneka ragam latar belakang. Masyarakat Surabaya ini kan masyarakat urban dan heterogen, jadi orang selalu bertanya tarian khasnya Surabaya itu apa sih, yang mana sih. oleh karena itu tarian ini tercipta dengan nuansa kekinian, baik ragam gerak yang mengacu pada motif khas Jawa Timur, maupun pada sentuhan musik tradisional yang mengiringinya,"

Dan saat ditanya kembali mengenai nama tarian Sparkling Surabaya, Diaztiami Azhar mengatakan bahwa:

"Sparkling artinya berkilau seperti bintang, dengan lima titik kilau yang dimiliki bintang, tarian ini mencoba mengambil keunikan dan kekhasan yang dimiliki masing-masing wilayah Surabaya, dari Surabaya Barat, Timur, Selatan, Utara dan Tengah."

Kepala bidang pemasaran pariwisata Dra. Susarinigsih, MM juga mengatakan bahwa:

"Nama sparkling dipilih secara filosofis untuk menghilangkan kesan Surabaya sebagai kota yang panas dan gersang. Oleh karena itu busana tarian ini juga didominasi warna hijau untuk memberi kesan dingin dan sejuk, juga warna emas untuk memancarkan kilau tarian ini."
Tari Sparkling Surabaya merupakan salah satu karya kreasi baru yang berpijak tentang kota Surabaya. Pada perkembangannnya, karya ini masih bertahan sebagai karya yang terus ditampilkan dalam menyambut kota Surabaya. Sejak tahun 2008 karya tari Sparkling Surabaya digunakan Dinas Pariwisata Surabaya sebagai promosi tentang kota Surabaya. Hal tersebut merupakan salah satu upaya Dinas Pariwisata dalam mengenalkan Surabaya melalui seni tari.

Sejak dicanangkan konsep logo Sparkling Surabaya pada tahun 2005, pemerintah terus berusaha untuk mengupayakan promosi yang begitu gencar. Salah satu promosi yang dapat dilakukan melalui seni tari. Untuk itulah hadirnya tari Sparkling Surabaya memberikan sumbangan berarti bagi pemerintah dalam membantu promosi Surabaya. tari Sparkling Surabaya adalah bagian dalam mempresentasikan kota Surabaya. Artinya tari Sparkling Surabaya merupakan identitas dari kota Surabaya.

Identitas yang dibangun melalui seni tari sebagai bagian dalam mempromosikan kota Surabaya. Ini merupakan bukti pemerintah akan keseriusan dalam membangun kota Surabaya melalui promosi dengan menggunakan seni tari. Jadi seni tari tidak hanya digunakan sebagai hiburan saja tapi bisa untuk kepentingan lainnya. Melihat hal itu, upaya yang dilakukan pemerintah benar-benar serius dalam menempatkan tari Sparkling Surabaya sebagai karya yang mampu memberikan hal yang terbaik bagi kota Surabaya.

Keberadaannya sangat dibutuhkan pemerintah guna kepentingan dalam membangun kota Surabaya. Memajukan kota dengan menarik perhatian para wisatawan untuk dapat berkunjung. Dengan begitu Surabaya akan dikenal semua orang sehingga berdampak pada pendapatan masyarakat Surabaya. Tari Sparkling Surabaya membawa sebuah nilai akan keberadahan kota Surabaya saat ini. Nilai yang dibangun melalui konsep yang matang dari berbagai persoalan tentang Surabaya.

Tentu ini membawa kebaruan membawa Surabaya dengan konsep seni sebagai media dalam menyampaikan pesan 
atau promosi. Mengisahkan akan identitas Surabaya sebagai kota yang banyak memberikan cerita. Hadirnya tari Sparkling Surabaya juga memberikan perwujudtan akan wacana tentang kota Surabaya. Wacana yang diperuntukkan bagi semua orang yang melihat
Surabaya dengan bentuk yang lain. Sebuah bentuk karya tari yang dapat direspon sehingga terbentuklah opini akan hasilnya. Berbagai opini itulah yang pada akhirnya dapat memberikan pengakuan atas karya tari Sparkling Surabaya.

Gambar 4.3

Tari Sparkling Surabaya

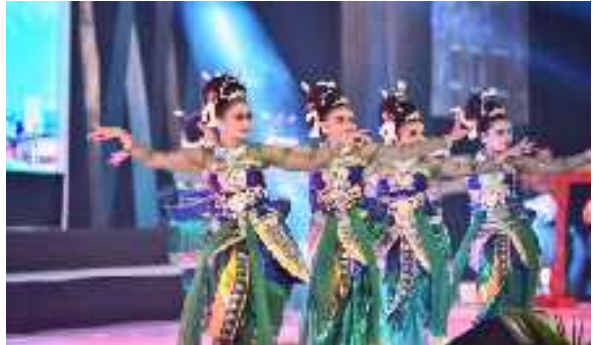

Sumber: Twitter Humas Kota Surabaya (@BanggaSurabaya, 2018)

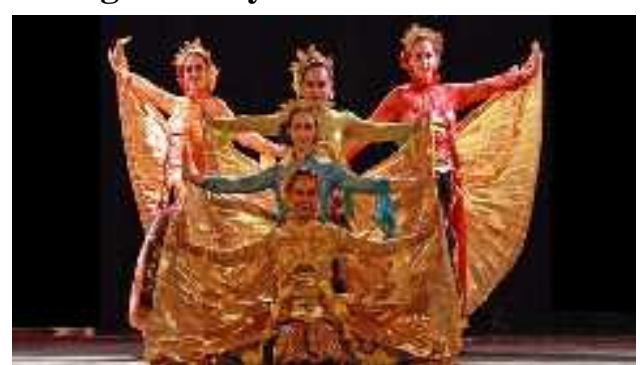

Sumber: Website Budaya Jawa (BudayaJawa, 2017)

Surabaya sebagai kota besar, penanaman pohon di sepanjang jalan menjadikan Surabaya ramah lingkungan. Artinya, Kota Surabaya diperindah dengan berbagai tanaman agar selalu sedap dipandang. Tentu semua itu dapat memberikan kenikmatan dan ketertarikan tersendiri.

Konsep dan arti dari logo Sparkling Surabaya sendiri diambil dari berbagai potensi wisata kota Surabaya yang dilihat dari segi geografis dan karakter destinasi wisata masing - masing. Tulisan Sparkling Surabaya yang menggunakan warna biru menunjukkan bahwa Surabaya merupakan kota pesisir, sedangkan warna hijau menunjukkan bahwa Surabaya adalah kota yang mengedepankan green and clean. Warna hijau juga mewakili kondisi Surabaya yang punya banyak lapangan golf bertaraf internasional.

Konsep ini tampil dalam visual lima bintang yang mewakili lima sub wilayah Surabaya (Surabaya utara, timur, barat, selatan, dan pusat) pada logo Sparkling Surabaya. Berbagai upaya yang dilakukan oleh pemerintah khususnya Dinas Pariwisata kota Surabaya melakukan promosi city branding melalui beberapa media promosi dan eventevent salah satunya event budaya tari Sparkling Surabaya.

Tarian Sparkling Surabaya juga diilhami oleh logo Surabaya, yaitu Sparkling Konsep ini lebih memfokuskan pada penghijauan dan kebersihan kota. Walaupun 
Surabaya yang dijadikan pemerintah kota sebagai city branding (produk kota). Logo yang diperkenalkan pada tahun 2005 tersebut telah menjadi slogan kota sebagai bentuk pengenalan terhadap kota Surabaya. Tentu logo itu merupakan bagian promosi dalam memperkenalkan Surabaya kepada dunia luar.

Melalui bahasa gerak, tari Sparkling Surabaya mencoba mengomunikasikan tentang struktur, makna simbol, dan identitas yang terkandung di dalamnya. Struktur yang dimaksud merupakan rangkaian gerak dan menjadi sebuah bentuk. Sedangkan makna simbol lebih pada sebuah pesan yang disampaikan, yaitu tentang kehidupan Kota Surabaya. Adapun identitas terkait dengan tari Sparkling Surabaya itu sendiri sebagai jati diri Kota Surabaya.

Tari Sparkling Surabaya sudah menjadi bagian promosi pemerintah kota dalam mengenalkan Surabaya di dunia luar. Ini menunjukkan bahwa karya tari ini mendapatkan legitimasi atau pengakuan dari pemerintah. Di sisi lain, karya tari ini digunakan sebagai pembelajaran di beberapa sekolah dan sanggar tari di Surabaya. Ini artinya bahwa karya tari ini mampu menunjukkan kualitasnya sebagai karya yang dapat memberikan sumbangan yang berarti bagi berbagai pihak.

Menjaga Surabaya menjadi tempat tujuan wisatawan adalah tugas pemerintah maupun masyarakatnya. Untuk itulah kehadiran tari Sparkling Surabaya adalah salah satu bukti bahwa untuk menjadikan Surabaya lebih dikenal dapat dilakukan melalui sebuah karya. Karya yang mampu memberikan sumbangan dan dapat bermanfaat bagi kota ini. Tentu ini salah satu upaya yang dilakukan koreografer dalam membangun kota Surabaya. Melalui karya seni tarinya koreografer ingin membangun image tentang kota tercinta ini. Mempromosikan sehingga dapat menjadi tempat destinasi bagi wisatawan lokal maupun manca negara.

\section{Daftar Pustaka}

Bagus, I. G. (2017). Pemasaran Pariwisata. Yogyakarta: ANDI OFFSET.

BudayaJawa. (2017, Juli 07). BudayaJawa. Retrieved Januari 20, 2020, from BudayaJawa: https://budayajawa.id/tari-sparklingsurabaya/

Bungin, B. (2015). Komunikasi Pariwisata Pemasaran dan Brand Destinasi. Jakarta: KENCANA.

Noor, A. (2017). Manajemen Event. Bandung: Alfabeta.

Sparkling Surabaya. (2015, Desember 1). Sparkling Surabaya. Retrieved Januari 20, 2020, from Sparkling Surabaya: https://sparkling.surabaya.go.id/

Sugiyono. (2017). Metode Penelitian Kuantitatif, Kualitatif, dan $R \& D$. Bandung: Alfabeta.

Yananda, R., \& Salamah, U. (2014). Branding Tempat. Jakarta: Makna Informasi.

@BanggaSurabaya. (2018, September 13). Twitter Humas Kota Surabaya. Retrieved Januari 20, 2020, from Twitter: https://twitter.com/banggasurabaya/sta tus/1040149636843896833 